\title{
急性感染症の指標としての末梢白血球のルミノール 依存性化学発光測定の意義
}

\author{
小橋 修・小橋悠紀子・山口佐和子・村西寿一・宮崎正之・ \\ 中西真之・林 真一郎・石橋正文 - 池田東吾 - 重松信昭*
}

\begin{abstract}
Role of whole blood luminol-dependent chemiluminescence on monitoring acute bacterial infections We have tested whether or not luminol-dependent chemiluminescence (CL) of whole blood can be used for monitoring an acute bacterial infection or acute episode of bacterial infection of patients with chronic infectious diseases. This assay has several serious problems to get a reliable and reproducible measurement, for example, diurnal and daily variation, changeable measurement by time after bleeding and contamination of red blood cells and plasma constituents. These shortcomings could be overcome by using $10 \mu l$ of whole blood instead of $100 \mu l$ of it and by measuring it within 30 minutes after bleeding at a certain fixed time for a patient. Acute bacterial infections, such as acute pneumonia or acute pleuritis induced a great increased CL response which turned to the normal level immediately after its recovery. The similar kinetics of CL response was observed at acute episode of patients with chronic infectious diseases. A very good correlation existed between CL response and clinical signs of acute bacterial infections, such as fever, increased erythrocyte sedimentation rate, leukocytosis $(r=0.73)$, increased CRP $(r=0.88)$. This assay can be used as one of the rapid and simple function tests of leukocytes for monitoring acute bacterial infections.

Osamu Kohashi $\bullet$ Yukiko Kohashi $\bullet$ Sawako Yamaguchi•Hisakazu Muranishi $\cdot$ Masayuki Miyazaki . Masayuki Nakanishi $\cdot$ Shinichiro Hayashi $\cdot$ Masafumi Ishibashi $\cdot$ Togo Ikeda $・$ Nobuaki Shigematsu* *Research Institute for Diseases of the Chest, Faculty of Medicine, Kyushu University key words: chemiluminescence, bacterial infections, whole blood, CRP, leukocyte test
\end{abstract}

人口の高秢化とともに, 種々の基礎疾患, 慢性疾患が 増え, かつ抗癌剂, 免疫調節剂や抗生物質の使用によ り, 延命は得られたものの, 免疫能沶よび感染防御能の 低下した, いわゆる immuno-compromised host \&增 加している.

このような状況のなかで細菌感染症は多様化し，菌交 代現象をはじめ, 日和見感染症や複合感染症が重要な問 題となっている. 発熱, 白血球増加, CRP 増加をはじ めとする急性炎症性反応が観察されたとき，これが感染 症に上るのか, あるい:基礎疾患の急性増悪によるのか を迅速に決めることは治療方針を立てるらえでたいへん 重要である. 感染症に和いて, その生体防御の主役とし て，免疫系の働く以前に和いても，また免疫系が作動し ているときに拈いても貪食細胞が重要な働きをしてい る ${ }^{1,2)}$. すなわち，貪食細胞は，病原体または抗体およ び補体でオプソニン化された病原体を頜食し, 消化し, 代謝することによって生体防御を司どっている。さら に, 貪食細胞は, $\mathrm{T}$ 細胞由来のリンホカインによって活 性化され, さらに強い生体防御を司どる細胞性免疫の担

\footnotetext{
*九州大学医学部胸部疾患研究施設
}

い手としても重要な働きをしている33.

近年, この貪食細胞の食機能が，細胞膜刺激後の活性 酸素産生能とょく相関すると報告されている ${ }^{4,5)}$ ，貪食 細胞のルミノール依存性化学発光 (luminol-dependent chemiluminescence) (CL) が食機能とよく相関すると されている6 . 筆者らも, この点に着目して当教室の入 院患者および外来患者の末梢白血球の CL 值を全血法? を用いて検討した。

末梢白血球の $\mathrm{CL}$ 值の測定には全血法 ${ }^{7}$ と分離白血 球 (PMN) 法9) とがあるが, 従来より末梢白血球の機 能検查として CL 值を用いる場合，いくつかの問題点 が指摘されてきたそそのなかでも日内変動があることと 採血後 CL 值の測定までの経過時間で大きな変動があ ること，すなわち再現性に乏しいことなどが指摘されて 扣り ${ }^{9)}$, このことが CL 值の測定を臨床検査としえな い大きい理由であった、筆者らは CL 值の日内変動, 採血から测定までの経時変化を詳細に検討し, 各個人に 決められた時間に採血すること，採血後 CL 值の測定 までの時間を一定にし，かつ，採血から測定までの時間 を30分以内とすることによって，再現性のよい CL 值 
を得ることができることを見いだした．かくして得られ た CL 值は, 急性感染症時の発熱反応, 白血球増多, 急性炎症性蛋白の出現などとよく相関して動くこと, 特 に臨床検査に打いて要求される簡便さと，迅速性に扣い てすぐれていることを見いだしたので報告する。

\section{対象と方法}

(1) 対 象

九州大学医学部附属胸部疾患研究施設呼吸器科入院中 の患者, 外来患者合計 60 名を対象にし, 対照健康成人と しては当科勤務医師10名を対象にした.

(1) 白血球の分離

ヘパリン加静脈血 $1 \sim 1.5 \mathrm{ml}$ を採血し，採血後 30 分 以内に以下に述べる方法で, ルミノール依存性化学発光 を測定した。一部の血液 $1 \mathrm{~m} l$ に対してデキストラン (Dextran MW 60000) $0.2 \mathrm{ml}$ を加光よく混和し, 室 温に 30〜45 分静置後デキストラン層 (Dx) を分離し, $1: 1(\mathrm{~V} / \mathrm{V})$ の割合でリンパ球分離液 (LSM) の上に 重層し， 1,500 rpm 30分間室温遠心した。 リンパ球と 単球を含む中間層と，遠心管底の顆粒球 (PMN) を分 離した．各細胞層をチュルク液にて染色し，細胞数をト ーマの計算盤にて400倍率の顕微鏡下に算定した·細胞分 画のためには，別に塗沫標本を作成して May Giemza 染色し白血球の分画をした.

(2) ルミノール依存性化学発光の試薬叔よび測定 白血球の膜刺激物質として, PMA (Phorbol myristic acetate, Sigma), zymosan A (Sigma), ルミノール (Sigma), 溶媒として dimetylsulfoxide(DMSO, Sigma), リン酸緩衝夜 (PBS 0.02 M pH 7.2), ハンクス液 (HBSS) を使用した。各試薬の濃度はそれぞれの至適 濃度を前報 ${ }^{9)}$ によてあらかじめ決定してから以下のよ らに調整した。 PMA (10mg)を $5 \mathrm{ml}$ のDMSO に溶解 ᄂ, $600 \mu l$ (PMA $2 \mathrm{mg} / \mathrm{ml}$ ) ずつ分注 し, $-20^{\circ} \mathrm{C}$ に保 存した. 使用時に PBS にて 4 倍に希釈した (PMA 0.5 $\mathrm{mg} / \mathrm{m} l)$.

zymozan A は, $20 \mathrm{mg} / \mathrm{m} l$ になるように蒸留水にて 調整し, $100^{\circ} \mathrm{C} 60$ 分煮沸後 $10 \mathrm{mg} / \mathrm{ml}$ になるように HBSS にて希釈し $4{ }^{\circ} \mathrm{C}$ に保存した. オプソニン化は, $\gamma$-globulin (ミドリ十字社, $50 \mathrm{mg} / \mathrm{ml}$ ) を 2 容に対し zymosan $(10 \mathrm{mg} / \mathrm{m} l) 1$ 容の割合でまぜ, $37^{\circ} \mathrm{C} 30$ 分反 応させ， 3 回 HBSS にて洗浄したあと $10 \mathrm{mg} / \mathrm{ml}$ の濃 度に HBSS にて調整し，分注して $4^{\circ} \mathrm{C}$ に保存した。 一部は, 健康人 4 名の新鮮血清拈よび $56^{\circ} \mathrm{C} 30$ 分非働 化血清を用いて同様にオプソニン化した。ルミノールは DMSO にて $(10 \mathrm{mg} / \mathrm{ml})$ になるように調整した.

(3) Biolumat LB9500T による CL の測定 血液または PMN 層を $10 \mu l$ 取り， HBSS $490 \mu l$ の 中にいれ，ただちに luminol $10 \mu l$ を加えよく混和後,

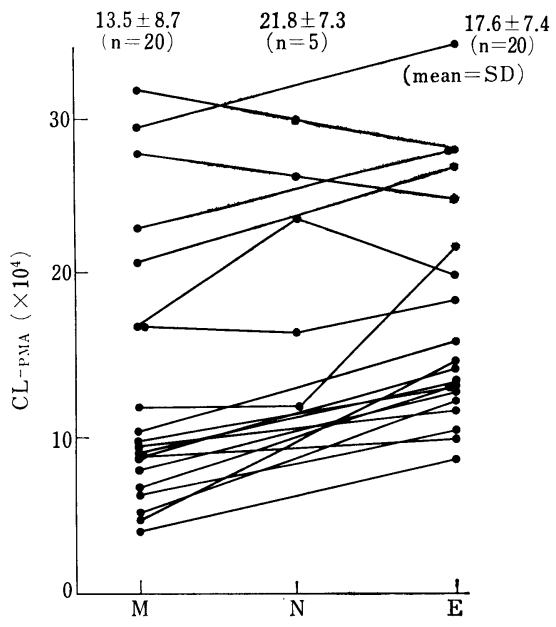

図 1 diurnal variation of CL response of whole bloods of 10 normal healthy adults $(n=20)$ $\mathrm{M}$ : morning. $\mathrm{N}$ : noon $\mathrm{E}$ : evening.

CL-PMA : CL response of whole blood stimulated by PMA $\left(\times 10^{4}\right.$ counts per $\left.3 \mathrm{~min}\right)$

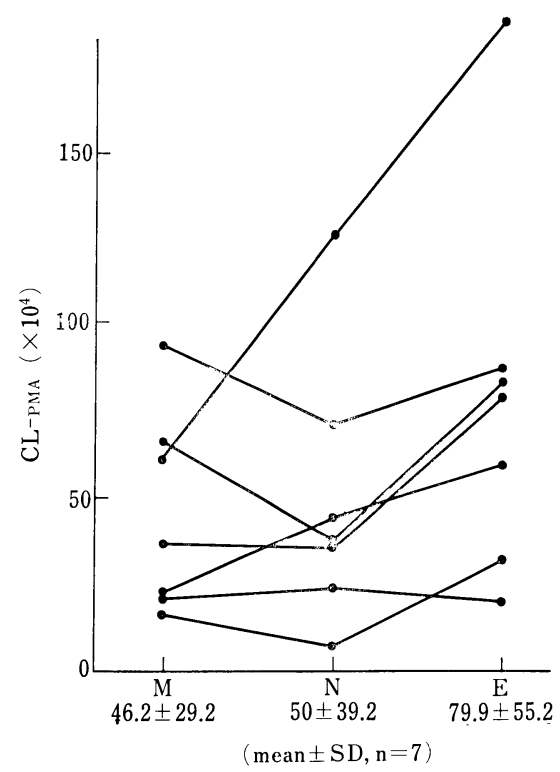

図 2 diurnal variation of CL response of whole bloods of seven patients with various respiratory diseases (See footnote of Fig. 1)

Biolumat にセットした. $37^{\circ} \mathrm{C} 5$ 分間反応後に， PMA $10 \mu l$ を加えよく混ぜたあと30分間反応させた，CL 值 はピーク CL 值前後の 3 分間の合計であらわした ${ }^{9}$ (.

\section{結 果}

（1） CL 值の日内変動

図 1 は, 健康人 10 名の末梢血液 $10 \mu \mathrm{l}$ による CL 值 $(\mathrm{n}=66)$ の日内変動を示した. 朝より夕方の CL 值が 高い值を与えたが有意差はなかった。一方，7名の入院 


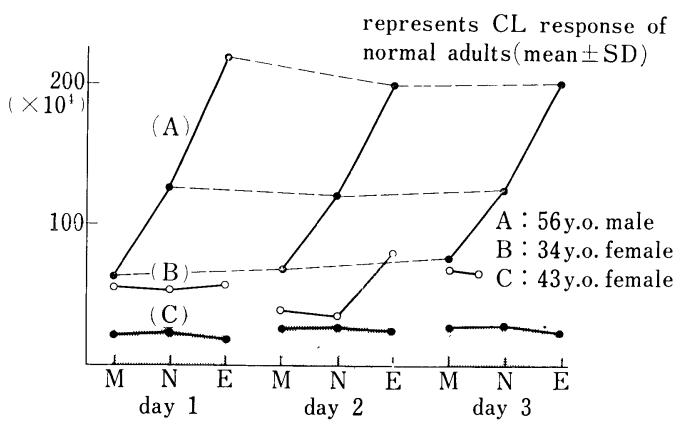

図 3 diurnal and daily variation during three consecutive days of $\mathrm{Cl}$ response of whole bloods from three patients with chronic pseudomonas infection of respiratory tract and from 10 normal healthy adults

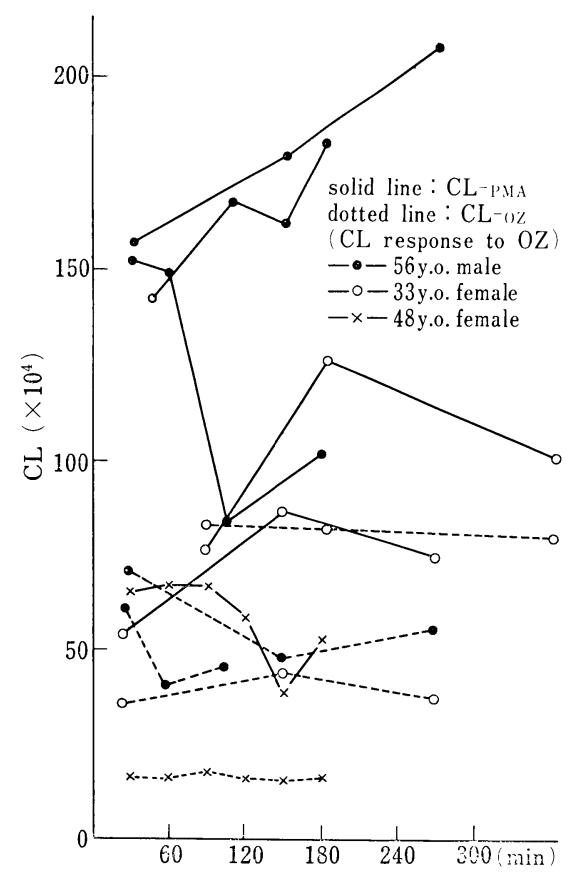

図 4 kinetics of CL response of whole blood at various intervals after bleeding

患者で調べると図 2 に示すように日内変動がより大きい ことが示された $(\mathrm{n}=21)$. 一方，これらの日内変動に 再現性があるかどらかを確かめるために，3名の患者の 3 日連続, 朝, 昼, 夕方の全血による CL 值の変動 $(\mathrm{n}=26)$ と健常人 10 名の $2 \sim 3$ 日連続朝夕 2 回の CL 值 $(\mathrm{n}=20)$ の変動を調べ, 図 3 に示した.

患者 3 名は, 臨床症状からほぼ安定期にある, 緑晨菌 による難治性呼吸器感染症の患者である。 3 日间連続し て，ほとんど日内変動を示さない人と大きく変動する人 とあったが，拈括む称とのに一定した日内変動を示し た. 健常人は図の斜線内に入った（朝 : $15.6 \pm 9.7$, 夕：

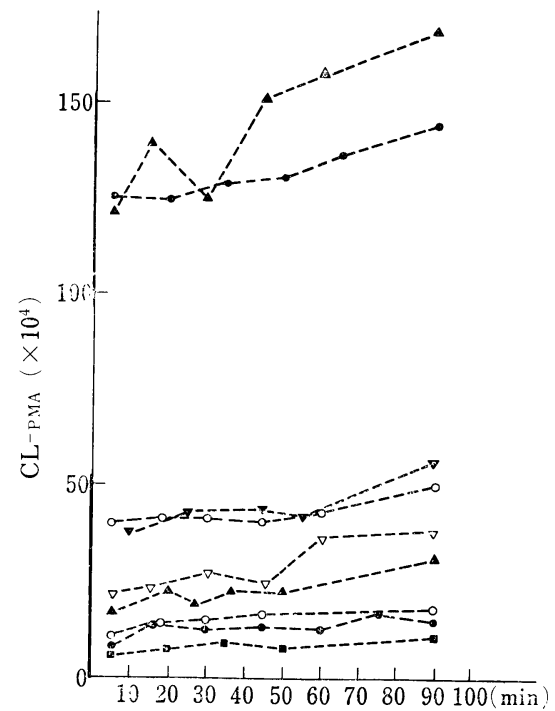

図 5 kinetics of CL response of whole blood at short periods after bleeding from patients and normal adults

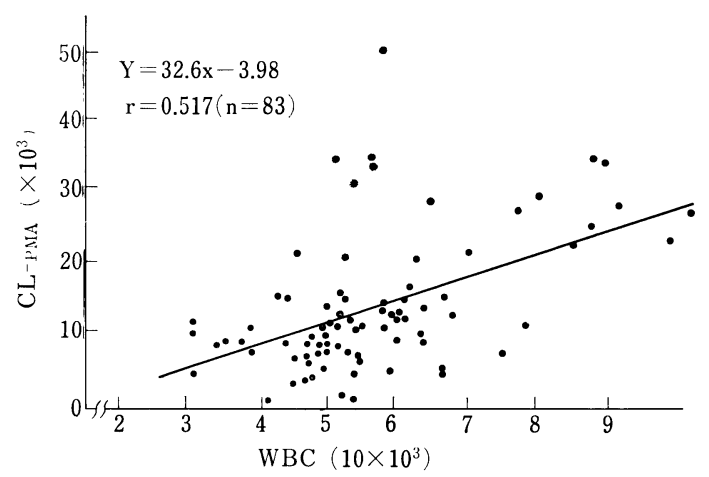

図 6 relationship between CL-PMA of whole blood and leukocyte counts of 10 normal healthy adults $(n=83)$

20.1土12.5).

（2）採血後測定時間までの経過時間による CL 值 の変動

採血後血液を氷上に放置し，一定時間ごとに CL 值 を測定し，CL 伯の経時变化を調べた（図 4). 採血後 1 時間を過ぎると，特に CL 值の変動は大きくなった. オプソニン化 zymosan による CL 值は，それ汪どの 変動はみられなかったが，PMA による CL 值は時間 変化が大きかった，さらに図 5 に示すように，採血から 90分以内の $\mathrm{CL}$ 值の変動を採血後，5，15，30，45分に わわて詳細に測定すると，CL 值の変動は15\%以内であ いた，ただし，高いCL 值を与える血液の場合には採 血後60分以内といえども，CL 值が大きく変動する例が あった。

（3）全血法に扔ける白血球数と CL 值との関係 


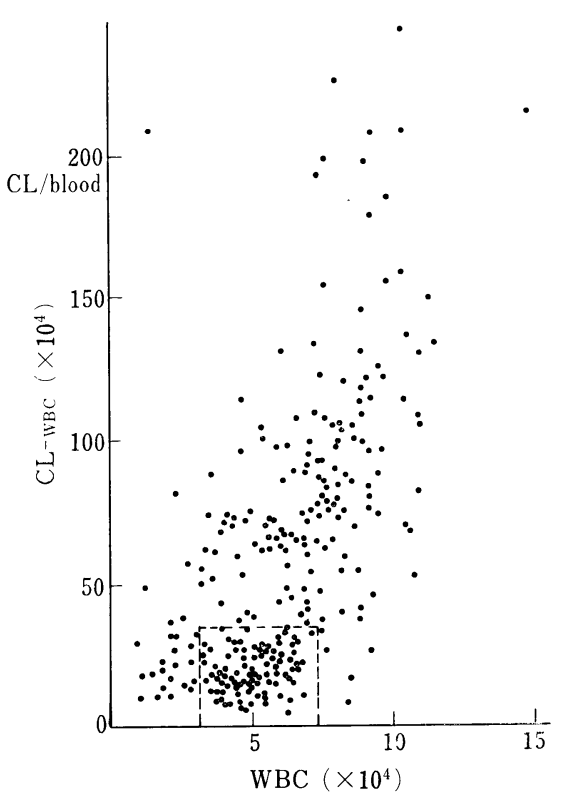

図 7 CL-PMA of whole blood (CL-WBC) vs WBC of 60 patients with various respiratory diseases and 10 normal healthy adults, during 3 months. The CL responses of the healthy adults were enclosed by a dotted line.

健常人 10 名の全血法による血液 $10 \mu l$ の CL 值と末 梢白血球数 (WBC) との関係を図 6 に示した。 この 10 名（n -83）のなかに白血球数が $9200,10350,8540$, 9825 と高值を示寸人がいたが，特に医学的に異常はなか ったので健常人に含めた．相関係数 $\mathrm{r}=0.517$ とあまり よい相関は得られなかった。データには示していない が，入院患者で長く経過が追え，かつこの間白血球数が 大きく変動した数名について，集団としてではなく個人 ごとにみた CL 值と白血球数との 関係についても, 相 関係数 $\mathrm{r}=0.3-0.6$ とやはりい相関は得られなかっ た。 また，過去 1 年間の CL 值のうちから無作為抽出 し, 全血法に抢ける白血球数と CL 值との関係を調べ た．無作為抽出された 170 検体の 血液 $10 \mu \mathrm{l}$ の CL 值 (CL/WBC) と, 細胞 1 個当たりの CL 值 (CL/cell) とを比較した（図 7，8）がいずれにおいてもよい相関関 係は認められなかった（相関係数 $\mathrm{r}=0.45, \mathrm{r}=0.40$ ). 図の枠内は 170 検体中に含まれた健常人の CL 值であ る.

\section{（4）急性感染症患者の急性期之回復期の CL 值の 比較}

困 9 に, 16 名の急性呼吸器感染症患者の急性期の CL 值と回復期の CL 值の比較を示した。発熱, 咳, 痰など の臨床症状を示し, 多くの場合, 白血球増加を示した急 性期には明らかに有意に高いCL 值を示し, 回復期に

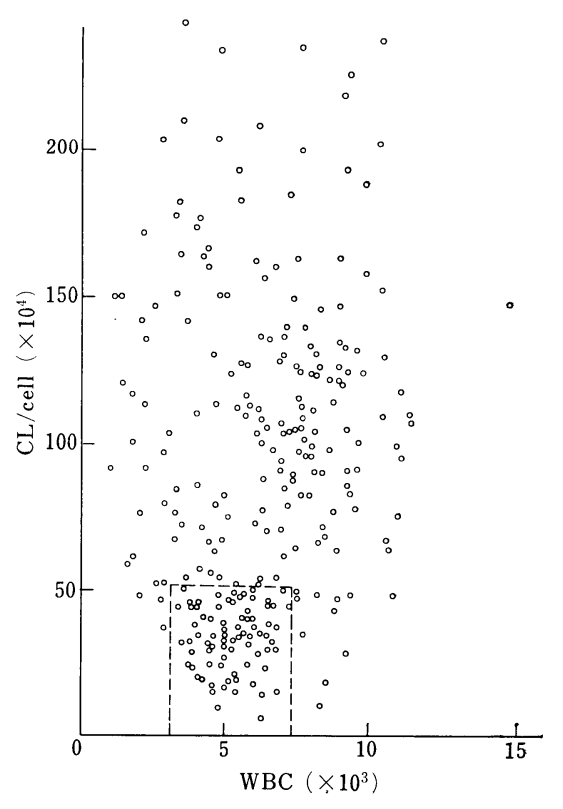

図 8 CL-PMA per leukocyte (CL/cell) vs WBC (See footnote of Fig. 7)

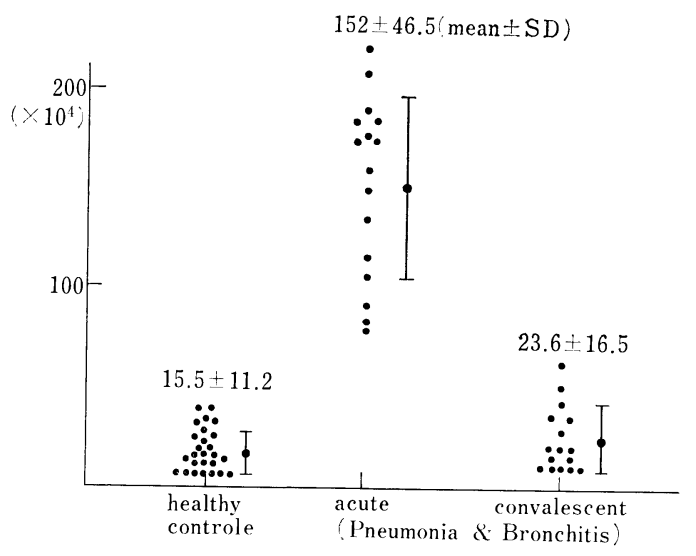

図 9 CL response of whole blood of 16 patients $(n=16)$ with acute episode of bacterial infection and of 6 normal healthy adults $(\mathrm{n}=26)$

CL-PMA : mean $\pm \mathrm{SD}\left(\times 10^{4}\right.$ counts per $\left.3 \mathrm{~min}\right)$

なると健常人とほぼ等しい CL 值に戻った。この 16 名 の CL 值と白血球数との関係を各個人別に図 10 に示し た。四 6 と図 7 とは明らかに異なり，急性感染症時には 白血球数の増加につれて CL 值も増加し, 両者間によ い相関（ $\mathrm{r}=0.731 ， \mathrm{n}=65)$ が認められた。 各個人別 にみると, 白血球数が増加すると必ず CL 值も増加し ていることがわかる。

（5） CL 值と他の急性炎症のパラメータである白血 球数抏よび CRPとの関係

CL 值の上昇が他の急性炎症のパラメータである CRP 


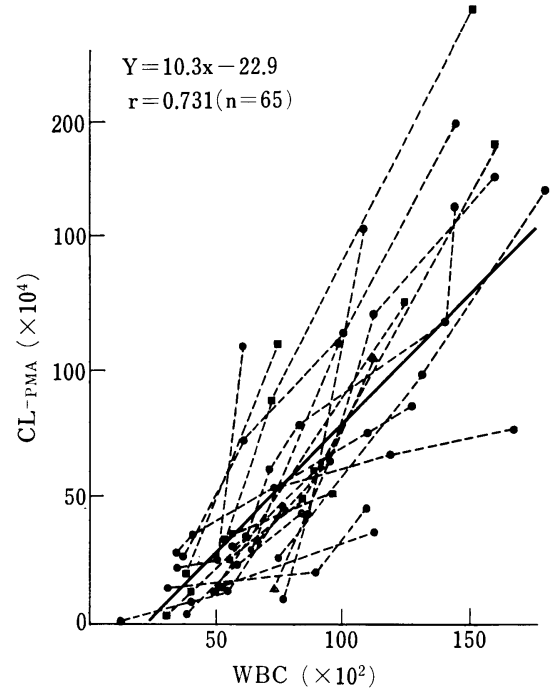

図 10 relationship between CL response of whole blood (CL-PMA) and leukocyte counts of 16 indivisual patients with acute bacterial infections $(\mathrm{n}=65)$

とどのような関係にあるかる調べた，38～ $39^{\circ} \mathrm{C}$ の発熱 を伴った典型的な急性肺炎，急性胸膜炎および急性気管 支炎患者で CRP と CL 值とを同時に測定しえた 14 名 について，急性期と回復期における CRP 值と CL 值と の関係を図11に示した。これらの患者は大部分が急性期 には発熱とともに CRP 值が 4 以上を示した。治療の開 始とともに，また臨床症状の改善とともに CRP は（十） から（一）となった。一方，CL 值は急性期には高值を示 し，臨床症状の改善とともに正常化した。CRP (一)を 0 とし, $\mathrm{CRP}( \pm)$ を 0.5 として図 11 の数值から CRP とCL 值との間の相関係数を計算すると, $\mathrm{r}=0.88(\mathrm{n}=$ 40)となり強い正の相関関係が認められた。

一方, 末梢白血球数は急性感染症のときに増加するが, 上記の14名の患者の末梢白血球数と CL 值との関係を 調べると, 相関係数 $\mathrm{r}=0.709(\mathrm{n}=37)$ と図10 と同様 によい相関が得られた，各個人別にみると，急性期の白 血球の増加に対して必ず CL 值も増加していることか ら両者の間にさらに強い相関関係が示唆された。

（6）慢性気道感染症 3 名の緑膿菌感染による急性恶 化時之回復期の CL 值の経過

つぎに慢性感染症の例において当教室に入院中の 3 名 の難治性慢性気道感染症患者の数力月間の入院期間中の CL 值を調べた。この期間中緑膿菌感染の悪化による発 熱, 赤沈促進, $\mathrm{CRP}$ 増加, $\mathrm{PaO}_{2}$ 低下, 呼吸困難, 痰の 増加などの臨床症状のあった急性感染症の時期 (acute infection) の CL 值を安定期之回復期 (stable and convalescent stage) の CL 值と比較した。 この 3 名はこの ような悪化と回復を $2 \sim 3$ 回繰り返したので, 安定期,

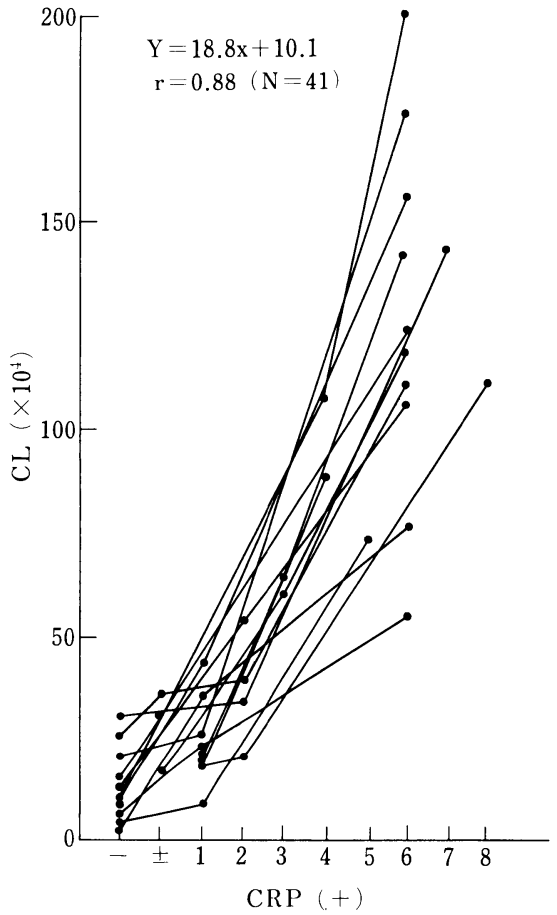

図 11 relationship between CRP and CL response of whole blood of 14 patients with acute pneumonia, acute pleuritis or acute bronchitis

急性期, 緩解明にわけて表 1 に示した，急性感染症時の CL 值は明らかに高く, 臨床症状, 臨床所見の改善につ れて CL 值は低下した。

\section{考 察}

本研究において, 末梢白血球の示すルミノール依存性 化学発光 (CL) は, 感染症の急性期に高值を示し, 回 復とともに正常化した。 またここの CL 值の動きは， 急性炎症の重要な臨床所見である CRP の増加や白血 球増加との間に強い正の相関関係を示した（図 $9 \sim 11$,

表 1). このことは，貪食細胞の示す活性酸素産生と食 機能との間によい相関関係があり，感染症によって食機 能が充進すること帛からもらなずける。一方，貪食細胞 は感染症のみならず，免疫複合体や補体によっても活性 化され ${ }^{10,11)}$ ，またリンフォカインによっても活性化され るので ${ }^{325)}$ ＣL 值が高值を示すことがただちに感染症 を示唆するとはいえない。

しかし，本研究の成績（図 9 ～11）から明らかなよう に，全血法による CL 值は，CRP や白血球増加と同様 に急性感染症の一つのよい指標として十分に役立てうる ことが判明した。しかし，末梢白血球の機能検査として この CL 值を臨床応用するに当って，日内変動が大き いことと測定值の再現性に問題があることが指摘されて 
表 1 CL response of three patients with chronic bronchitis or bronchiectasis during repeating infections with Pseudomonas aeruginosa

\begin{tabular}{|c|c|c|c|c|c|}
\hline \multirow[b]{2}{*}{ patients } & \multicolumn{4}{|c|}{ CL-PMA } & \\
\hline & \multicolumn{2}{|c|}{ stable } & \multicolumn{2}{|c|}{ acute infection } & convalescent \\
\hline (1) & $22.7 \pm 8.3$ & $(\mathrm{n}=8)^{* * *}$ & $61.8 \pm 5.3($ & $=8)^{* *}$ & $25.6 \pm 5.2(\mathrm{n}=8)$ \\
\hline$(2)$ & $41.0 \pm 10.7$ & $(\mathrm{n}=5)^{* *}$ & $120.7 \pm 23.6$ & $=6)^{*}$ & $75.0 \pm 18.3(\mathrm{n}=3)$ \\
\hline (3) & $81.8 \pm 10.8$ & $(\mathrm{n}=5)^{* * *}$ & $202.8 \pm 9.8($ & $=6)^{* * *}$ & $138.7 \pm 14.3(\mathrm{n}=3)$ \\
\hline
\end{tabular}

Statistical analysis was carried out by unpaired Student's $t$ test.

$* * \mathrm{P}<0.01 . \quad * \mathrm{P}<0.05$

きた。日内変動に関しては, 前報9) と同様に, 図 1 と図 2 とから容易にわかるように，健常人では泳ぼ一定であ るが患者間では変動が大きかった。しかし，図３に示す ように，3 日連続して测定した CL 值をみると，CL 值 の日内変動は個人個人でほぼ一定した值を示すと考光ら れた。これらの点を考虑すると，全血法による CL 值 を白血球の機能検査として用いる場合，患者ごとに採血 時間を決め，決められた時間に採血し測定すれば臨床応 用可能であると考えられた。測定時間が決められた時間 から大幅にずれた場合には，他日とのずれた時間に採血 し，前回と同一時間での CL 值を $2 \sim 3$ 回測定して日 内変動を確認し参考にする必要があった。

つぎに採血後の CL 值の経時変化については，人に よって非常にまちまちの経時的変化を示し, 採血から測 定までの時間が 60 分を超えると CL 值が大きくなった. その変動の仕方は同一人であっても，日によって大きく 異なった. 図 5 から採血後30分以内の測定であれば, CL 值の変動はかなり小さかった. 以上の問題を踏ま兄 て，(1) 採血時間をできる限り個人に決められた時間内 にすること, (2) 採血後30分以内に CL 值を測定し, かつ，(3) 採血から測定までの時間をできる限り各個人 において一定にすることを原則とし，CL 值の測定をす ることが重要である. 分離白血球の CL 值の测定の場 合には, PMN を分離し，その CL 值を測定するまで に採血後少なくとも 2 時間以上を要するので, 採血後, より早い時間内に測定できる全血法の汪うが，in vivo の白血球の CL 值をよりょく反映しているといえるか もしれない. しかし, 全血法の場合は分離 PMN と違 って多くの赤血球が混在するら光に，血清拈よび薬物な どの影響が加わる7,9,12). 通常, 全血法では $100 \mu l$ の血 液による測定がなされているが7)，本法の $10 \mu l$ にくらべ て，血漿成分や赤血球成分による影響が大きくなる.

私どもは, 先にこの問題を検討し, 全血 $100 \mu l$ のか わりに $10 \mu l$ による測定にかえることによって, 赤血球 成分および血清成分の影響を最少限にでさることを見い だした ${ }^{9)}$. CL 值は，前報で検討したように，各検体ご とについて調べると，その細胞数と CL 值との関係は直

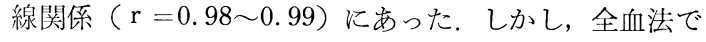
测定された CL 值に関しては, 健常人であれ, 患者で あれ, 集団としてみると CL 值と細胞数との関係は直 線関係を示さず, 細胞数とは無関係にばらばらの CL 值 を示した（図 6,7 ). このことの一つの説明は，もとも と細胞に準備されている活性酸素産生に係わる酵素の量 が，各個人によって異なっているとすれば，また同一人 であっても日によって酵素の量が異なっているとすれば 説明できる．この点は今後の問題である.

しかしながら少なくとも急性感染症の場合, 図 10,11 に示すように, CL 值は急性感染症のよい指標とされて いる CRP や白血球数との間に正の相関関係が認めら れたこと,さらにデータには示していないが, 全血法で 測定した CL 值は, 発熱, 赤沈促進ともよい相関を示 したので, この全血法による CL 值は急性感染症のよい 指標として, 十分臨床応用可能と考えられる。ささらに, 各個人別にみた図 10 の成績から, 白血球数の増加率と CL 值の増加率とは, 各個人別にみると明らかに異なっ て扣り，CL 值は白血球数の反映としてのみでなく，白 血球の機能の克進状態を知るらえで重要な情報を与えて いるといえる.

さて, 白血球の示す CL 值は, 細菌感染のときに上 昇し, ウイルス感染では抑制されるという報告があ る $^{13,14)}$ が，逆にウイルス感染でも上昇するといら報告も ある、本研究ではウィルス感染の患者は含まれていない ので,この点の確認はできなかった。な和症例を重ねて 検討する必要がある。

以上, 全血法による末梢白血球の CL 值が, 細菌感染 症の急性期に著明に上昇すること, 回復期には正常化す ること, CL 值の絶対值には個体差があること, 日内変 動は健常人では, それほど大きくないが，患者では大き いことを示した. さらに, 日常臨床の場にあって発熱, 赤沈促進 CRPをはじめとする急性炎症性蛋白の出現な どがあったとき，これが基礎疾患（たとえば膠原病, 悪 性腫瘍など）そのものの増悪によるのか, それとも感染 症によるものかを, 白血球の機能検査の一つとして全血 法による CL 值の測定によって，迅速にかつ簡単に鑑 
別できれば，たいへん重要な検査になるに違いない。

本研究は厚生省の研究費の援助を受忷た。また, 本研 究の一部は第19回日本胸部疾患九州地方会に拈いて発表 した。

\section{文 献}

1) Mackaness, G.B.: The mechanism of macrophage activation. Infectious Agents and Host Reactions. ed. S. Mudd. W.B. Sounders Company. Philadelphia, 1970, p 61 .

2) Klebanoff, S.J.: Antimicrobial mechanisms in neutrophilic polymorphonuclear leukocytes. Semin. Hematol. 12: 117-142, 1975.

3) Nathan, C.F., Karnovsky, M.L., David, J.R.: Alterations of macrophage functions by mediators from lymphocytes. J. Exp. Med. 133: 13561376, 1971.

4) Babior, B.M.: Oxygen-dependent microbial killing by phagocytes (first of two parts). N. Engl. J. Med. 298: 659-668, 1978.

5) Johnston, R.B. Jr., Godzik, C.A., Cohn, Z.A.: Increased superoxide anion production by immunologically activated and chemically elicited macrophages. J. Exp. Med. 148: 1151978.

6) Cheson, B.D., Christensen R.L., Sperling, R., Kohler, B.E., Babior, B.M.: The origin of the chemiluminescence of phagocytosing granulocytes. J. Clin. Invest. 58: 789-796, 1976.

7) Kato, T., Wokalek, H., Schopf, E., Eggert, H., Ernst, M., Rietschel, E.Th., Fischer, H.: Measuremnt of chemiluminescence in freshly drawn human blood. I. Role of granulocytes, platelets. and plasma factors in zymosaninduced chemiluminescence. Klin. Wochenschr. 59: 203-211, 1981.

8) Allen, R.C., Stjernholm, R.L., Steele, H.:
Evidence for the generation of an electronic exitation state(s) in human polymorphonuclear leukocytes and its participation in bactericidal activity. Biochem. Biophys. Res. Commun. 47: 679-684, 1972.

9) Kohashi, O., Kohashi, Y., Toyoshima, S., Shigematsu, N.: A simple and rapid microtechnique for studying a luminol-dependent chemiluminescence of whole blood. Jap. J. Inf. 5: 193-272, 1985.

10) Wright, S.D., Silverste., S.C.: Receptors for $\mathrm{C} 3 \mathrm{~b}$ and $\mathrm{C} 3 \mathrm{bi}$ promote phagocytosis but not the release of toxic oxygen from human phagocytes. J. Exp. Med. 158: 2016-2023, 1983.

11) Leijh, P.C.J., van der Barselaar, M.Th., van Zwet, T.L., Daha, M.r., van Furth, R.: Requirement of extracellular complement and immunoglobulin for intracellular killing of micro-organisms by human monocytes. J. Clin. Invest. 63: 772-784, 1979.

12) Faden, H., Maciejewsky, N.: Whole blood luminol-dependent chemiluminescence. J. Reticuloendothel. Soc. 30: 219-226, 1981.

13) Abramson J.S., Mills, E.L., Giebink, G.S., Quie, P.G.: Depression of monocye and polymorphonuclear leukocyte oxidative metabolism and bactericidal capacity by influenza $\mathrm{A}$ virus. Infect. Immun. 35: 350-355, 1982.

14) Abramson, J.S., Lewis, J.C., Lyles, D.S., Heller, K.A.: Inhibition of neutrophil lysosome-phagosome fusion associated with influenza virus infectionin in vitro. Role in depressed bactericidal activity. J. Clin. Invest. 69: 1393-1397, 1982.

15) Shult, P.A., Dick, E.C., Joiner, K.A., Busse, W.W.: Role of serum in stimulation of polymorphonuclear leukocyte luminol-dependent chemiluminescence by influenza A. Am. Rev. Respir. Dis. 131: 267-272, 1985. 